This paper has been submitted for publication in ENVIRONMENTAL CHALLENGES. Please note that the manuscript has yet to be formally accepted for publication. Subsequent versions of this manuscript may have slightly different contents. Please feel free to contact the correspondence author(s); We welcome every feedback. 


\title{
Nature Based Solutions for Sustainable Urban Storm Water Management in Global South: A Short Review
}

\author{
Fahad Ahmed ${ }^{1,2}$, Shashwat Sharma ${ }^{1}$, Ho Huu Loc ${ }^{1,},{ }^{*}$, Ming Fai Chow ${ }^{3}$ \\ ${ }^{1}$ Water Engineering and Management, Asian Institute of Technology (AIT) \\ Klong Luang, Pathum Thani, 12120, Thailand \\ ${ }^{2}$ Department of Civil Engineering, University of Sargodha \\ Sargodha, 40100, Pakistan \\ ${ }^{3}$ Discipline of Civil Engineering, School of Engineering, Monash University Malaysia \\ *Corresponding author's E-mail: hohuuloc@ait.asia
}

\begin{abstract}
Rapid urbanization in the Global South exacerbates urban water management challenges such as urban flooding and water pollution, rendering many areas water-insecure. Our reliance on grey infrastructures to combat these water management challenges is not sustainable in the long run, due to which a better alternative must be sought. Nature-based Solution (NBS) promote ecosystem services and enhance climate resiliency along with flood control and improvement of water quality by utilizing natural elements including green spaces and water bodies within the urban environment. In the past few decades, NBS have been adapted for urban drainage in Global North and evolved by means of various terms based on geographic location, practices and applications. Some of these wellknown terms include Low Impact Development (LIDs), Sustainable Urban Drainage Systems (SUDS), Water Sensitive Urban Design (WSUD) and Best Management Practices (BMPs). The transition towards a resilient and sustainable environment has been made possible through the application of NBS. Recently, countries in the Global South such as Singapore, Malaysia, Vietnam, and Thailand are trying to alter urban storm water management strategies through conversion of grey infrastructure to green infrastructure by employing various NBS techniques. The findings of this study show how NBS has influenced the Global South's urban water management.
\end{abstract}

Keywords-Nature Based Solutions; Sustainable Urban Water Management; Global South

\section{INTRODUCTION}

The global population is growing at such a rapid rate that by 2050, over 2600 million new people will be living in cities (a 68 percent increase) (UNDESA, 2012). Rapid and unplanned urbanizations, mainly in large urban areas, have led in increased impervious surfaces and, as a result, greater runoff volumes and rates. Climate change is anticipated to raise the frequency and severity of rainfall events, putting additional strain on urban hydrology and escalating the dangers of flooding (Revi et al., 2014).

The discharge of various contaminants from point and non-point sources into surface waterways in considerable volumes is triggered by heightened anthropogenic activity along with changes in land use and cover (Kabir et al., 2014). Due to washout and the deposition of various contaminants, the quality of receiving waters deteriorates during storm events. Stormwater runoff transfers and accumulates a wide range of contaminants into bodies of water, from heavy metals and pathogens to organic debris and suspended particles (Loc et al. 2015\&2017; Muerdter et al., 2018; Nguyen et al. 2019).

Traditional stormwater management focuses on reducing flood danger by directing surface runoff to drains and stream discharge. Although it aids in the reduction of ponding and flooding, it lacks sufficient water quality management, preventing the application of stormwater for both non-potable and potable uses (Spahr et al., 2020).

Through natural processes involving vegetation and soil, non-conventional or alternative stormwater runoff management systems have evolved with the goal of improving runoff quality, promoting evapotranspiration, and reducing surface runoff amount (Dagenais et al., 2018). 
These approaches have experienced wide-ranging adoption in the Global North under various names, including SUDS (sustainable urban drainage system) in the United Kingdom (CIRIA, 2015), Water Sensitive Urban Designs (WSUD) in Australia (Water by Design, 2014), LID (low impact development) and best management practice (BMP) in North America (Fletcher et al., 2015), and Green and Blue Infrastructure in European countries (Fletcher et al., 2015; European Commission, 2019). For Global South only few countries have adapted these approaches including Sponge Cities in China (Ren et al., 2017), Singapore (ABC Waters Programme) (PUB, 2018) and Malaysia (MSMA) (DID, 2012).

The growth in usages of urban drainage terminologies like NBS, GI, BMP, SUDs, LIDs, WSUDs, and SCMs etc. has been exponential in recent times. This growth is clear evidence of a heightened social interest in urban stormwater management over recent decades. It also demonstrates the increasingly integrated nature of urban drainage as a discipline, historically part of civil engineering, with a growing focus on the ecology of receiving waters and the delivery of multiple benefits (USEPA, 2013). BMPs in North America and SuDS in the United Kingdom-all have local roots, and only a few have gained widespread attention. For example, Australia and Europe accounted for 93 of the 352 annual citations for BMP literatures related to stormwater from 2005 to 2009. Similarly, the Australian phrase WSUD was referenced on 335 instances annually between 2010 and 2012, with 75 of those citations connected to European approaches.

As a result, urban drainage has evolved substantially in recent years, shifting from a focal point of flood protection and health security to one that considers a wide-ranging domain of environmental, sanitary, and socioeconomic considerations. Therefore, new terminology has arisen to better depict these new technologies, and as the world progresses toward a more sustainable and integrated approach, this trend is projected to continue in the near future (Fletcher et al., 2015).

The Global South is facing challenges which include aging infrastructure, depleted resources, and changing precipitation patterns in the face of growing and competing demands. Furthermore, climate change raises the likelihood of higher and more erratic precipitation, which might result in severe floods and long-term droughts. Furthermore, through producing changes in hydrological systems, urbanization has an impact on the quality and quantity of water supplies (IPCC, 2014). As a result, certain alternative solutions, or what we can term Nature-based solutions, must be adopted in order to alleviate the repercussions of the grey infrastructure gap. This will necessitate the employment of NBS to pay off for the dwindling quantity and quality of citizens' water sources, which rely on environmentally sensitive "natural" processes for their urban water security.

Several "sustainable" phrases for urban water management have emerged, particularly in industrialized countries with temperate climates. Consequently, we're seeing waves of paradigm shifts as these schools of thought are conveyed to developing countries, either through scientific research conducted by graduate students from these countries or through ODA-funded consultancy projects. Despite the fast growing literature, real application of those terminologies in poor countries of the Global South remains limited due to a range of ground-level constraints like as limited resources and changing hydrometeorological conditions. As a result of this research, it may be possible to make a more informed decision about which terminology to adapt, as well as get a better understanding of various terminologies. It would also help city planners and developers make more educated judgments about which urban water management terminologies to utilize.

\section{METHODS}

The "Scopus" database was searched for articles describing the application of Nature-based Solutions for urban water management in the Global South. "Nature based Solutions" or "Low Impact Development" or "Green Infrastructure" or "Urban water Management" or "Water Sensitive Urban Design" were the keywords we used in our "Scopus" search. The publication period was limited from 2000 to 2021. Following the receipt of search results, we narrowed the search by limiting articles about the application of nature-based solutions for urban water management in the Global South. In China, Hong Kong, Thailand, Malaysia, Brazil, and Africa, we looked at 20 NBS applications for urban water management.

Furthermore, different NBS techniques are discussed in Table 1 and compared with each other. 
TABLE 1: COMPARISON OF DIFFERENT NBS TECHNIQUES WITH BENEFITS

\begin{tabular}{|c|c|c|c|c|}
\hline SN & NBS Technique & Description & \multicolumn{2}{|c|}{ Benefits } \\
\hline 1 & $\begin{array}{l}\text { Rainwater } \\
\text { harvesting } \\
\text { Rain Barrels }\end{array}$ & $\begin{array}{l}\text { Rain barrels are the containers } \\
\text { which collect stormwater from roofs } \\
\text { and the water can be reused for } \\
\text { potable or non-potable purposes in } \\
\text { dry periods. }\end{array}$ & & $\begin{array}{l}\text { Iditional water supply source } \\
\text { event urban flooding }\end{array}$ \\
\hline 2 & Green roofs & $\begin{array}{l}\text { Green roofs have soil layer and a } \\
\text { special drainage mat material which } \\
\text { convey surplus stormwater from the } \\
\text { roof to the drainage system }\end{array}$ & $\begin{array}{l}\text { i. } \\
\text { ii. } \\
\text { iii. } \\
\text { iv. } \\
\text { v. } \\
\text { vi. } \\
\text { vii. }\end{array}$ & $\begin{array}{l}\text { Reduced runoff peaks and volumes } \\
\text { Lower flood risks } \\
\text { Insulation of heat transfer } \\
\text { Low cost for air-conditioning } \\
\text { Reduced heat island effect } \\
\text { Reduced Air pollution } \\
\text { Increased biodiversity }\end{array}$ \\
\hline 3 & $\begin{array}{l}\text { Rain Gardens/ } \\
\text { Bioretention } \\
\text { systems }\end{array}$ & $\begin{array}{l}\text { Rain Gardens or Bioretention } \\
\text { systems are depressions in soil that } \\
\text { contain vegetation in an engineered } \\
\text { soil above a gravel / sand drainage } \\
\text { bed. It provides storage, } \\
\text { evaporation and infiltration. }\end{array}$ & $\begin{array}{l}\text { i. } \\
\text { ii. } \\
\text { iii. } \\
\text { iv. } \\
\text { v. } \\
\text { vi. }\end{array}$ & $\begin{array}{l}\text { Reduced runoff peaks and volumes } \\
\text { Improved water quality } \\
\text { Lower flood risks } \\
\text { Reduced Air pollution } \\
\text { Prevent urban flooding } \\
\text { Increased biodiversity }\end{array}$ \\
\hline 4 & $\begin{array}{l}\text { Pervious } \\
\text { pavements }\end{array}$ & $\begin{array}{l}\text { Permeable pavements are the } \\
\text { pavements made by gravel and } \\
\text { paved by porous concrete or paving } \\
\text { block or porous bricks which can } \\
\text { infiltrate rainwater and convey } \\
\text { water to drainage system. }\end{array}$ & $\begin{array}{l}\text { i. } \\
\text { ii. } \\
\text { iii. } \\
\text { iv. }\end{array}$ & $\begin{array}{l}\text { Reduced runoff peaks and volumes } \\
\text { Lower flood risks } \\
\text { Improved water quality } \\
\text { Prevent urban flooding }\end{array}$ \\
\hline 5 & $\begin{array}{l}\text { Infiltration } \\
\text { trenches }\end{array}$ & $\begin{array}{l}\text { Infiltration trenches are the narrow } \\
\text { ditches filled with gravel to intercept } \\
\text { runoff from the impervious area } \\
\text { present at upslope. }\end{array}$ & $\begin{array}{l}\text { i. } \\
\text { ii. } \\
\text { iii. }\end{array}$ & $\begin{array}{l}\text { Reduced runoff volumes } \\
\text { Lower flood risks } \\
\text { Prevent urban flooding }\end{array}$ \\
\hline 6 & $\begin{array}{l}\text { Vegetative } \\
\text { swales }\end{array}$ & $\begin{array}{l}\text { Vegetative swales are the channels } \\
\text { with sloping sides covered with } \\
\text { vegetation or grass. It collects the } \\
\text { stormwater and conveys and } \\
\text { infiltrates it. }\end{array}$ & $\begin{array}{l}\text { i. } \\
\text { ii. } \\
\text { iii. } \\
\text { iv. }\end{array}$ & $\begin{array}{l}\text { Reduced runoff peaks and volumes } \\
\text { Lower flood risks } \\
\text { Improved water quality } \\
\text { Prevent urban flooding }\end{array}$ \\
\hline
\end{tabular}

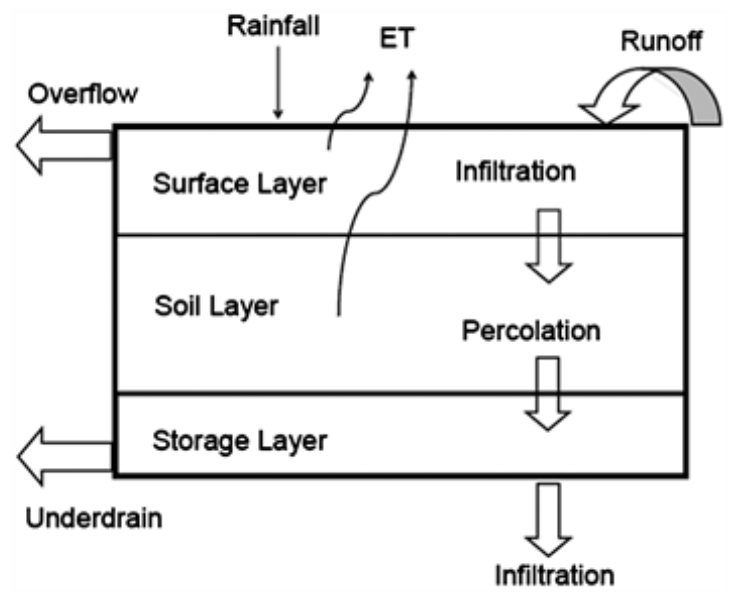

Fig. 1. Typical Structure of vertical layers in Bioretention system (Adapted from USEPA., 2000) 


\section{RESULTS AND DISCUSSIONS}

\subsection{THE LITERATURE}

The list of noteworthy research on sustainable water management techniques in the global south is presented in Table 2. It should be noted that the list presented is nowhere near exhaustion since this paper is intentionally position as a "short review". China, including Hong Kong, has the most studies, with ten, followed by Malaysia, which has four, and Thailand and Brazil, which each have two. Ethiopia (East Africa) and South Africa are the other countries with one study each. Modeling, which consists of 13 investigations that are either physical or numerical in nature, is the predominant approach of the methodology. Field-based monitoring paired with social surveys is another noteworthy strategy. The most popular types of NBS and the associations are bioretention cells. Moreover, different terminologies have been used and followed in the studies; among them for China and Hong Kong mostly LID and Sponge city were used. Whereas, for Malaysia the emphasis was on MSMA and BMP as the guidelines for MSMA have been developed from BMPs. For Thailand, the term NBS is mostly used as it is a new and evolving term there for urban water management. For South Africa no specific term was found while for South America (Brazil) LID term was utilized. 
TABLE 2: APPLICATIONS OF NBS IN GLOBAL SOUTH.

\begin{tabular}{|c|c|c|c|c|c|c|c|}
\hline SN & Documents & Study aims & $\begin{array}{l}\text { Geographic } \\
\text { al region }\end{array}$ & Methods & Terminologies & Type of NBS & Key Findings \\
\hline 1 & $\begin{array}{l}\text { Yang and } \\
\text { Chui., } 2018\end{array}$ & $\begin{array}{l}\text { To propose a method for } \\
\text { formulating suitable sizing } \\
\text { criteria for multi-objective } \\
\text { stormwater management. }\end{array}$ & Hong Kong & $\begin{array}{l}\text { Numerical } \\
\text { modelling }\end{array}$ & LID & Bio-retention system & $\begin{array}{l}\text { Lowered runoff volume and } \\
\text { peak flow }\end{array}$ \\
\hline 2 & $\begin{array}{l}\text { Gao et al., } \\
2021\end{array}$ & $\begin{array}{l}\text { To simulate the effect for the } \\
\text { combinations of LID facilities. }\end{array}$ & China & $\begin{array}{l}\text { Numerical } \\
\text { modelling }\end{array}$ & LID & $\begin{array}{l}\text { Rain garden, Green } \\
\text { roof, Permeable } \\
\text { pavement }\end{array}$ & $\begin{array}{l}\text { i. Improved runoff control rate } \\
\text { ii. Improved SS load reduction } \\
\text { rate } \\
\text { iii. Combined NBS facilities have } \\
\text { better regulatory effects than } \\
\text { single NBS facility }\end{array}$ \\
\hline 3 & $\begin{array}{l}\text { Zhang et al., } \\
2020\end{array}$ & $\begin{array}{l}\text { To evaluate the Sponge City } \\
\text { strategy's control of stormwater } \\
\text { runoff volume and quality. }\end{array}$ & China & $\begin{array}{l}\text { Numerical } \\
\text { modelling }\end{array}$ & $\begin{array}{l}\text { Sponge City and } \\
\text { LID }\end{array}$ & $\begin{array}{l}\text { Rain Garden, } \\
\text { Bioretention, Grass } \\
\text { pitch }\end{array}$ & $\begin{array}{l}\text { i. Reduced flooding risks } \\
\text { ii. Maintained water quality } \\
\text { iii. Improved ecosystem services }\end{array}$ \\
\hline 4 & $\begin{array}{l}\text { You et al., } \\
2019\end{array}$ & $\begin{array}{l}\text { To evaluate the performance of } \\
\text { bioretention systems with } \\
\text { alkaline solid wastes }\end{array}$ & China & $\begin{array}{l}\text { Physical } \\
\text { Modelling }\end{array}$ & BMP & Bio-retention system & $\begin{array}{l}\text { Enhanced removal of nutrients } \\
\text { (Phosphorus and Nitrogen) in a } \\
\text { simulated stormwater runoff }\end{array}$ \\
\hline 5 & $\begin{array}{l}\text { Luo et al., } \\
2020\end{array}$ & $\begin{array}{l}\text { To investigate the performance } \\
\text { of bilayer media bioretention } \\
\text { system }\end{array}$ & China & $\begin{array}{l}\text { Physical } \\
\text { Modelling }\end{array}$ & Sponge City & Bio-retention system & $\begin{array}{l}\text { i. Higher Nitrogen removal } \\
\text { efficiency } \\
\text { ii. Longer hydraulic residence }\end{array}$ \\
\hline 6 & $\begin{array}{l}\text { Mai and } \\
\text { Huang.,2021 }\end{array}$ & $\begin{array}{l}\text { To investigate the performance } \\
\text { of biochar-amended bioretention } \\
\text { facilities }\end{array}$ & China & $\begin{array}{l}\text { Physical } \\
\text { Modelling }\end{array}$ & $\begin{array}{l}\text { Sponge City and } \\
\text { LID }\end{array}$ & Bio-retention system & $\begin{array}{l}\text { NBS can effectively control } \\
\text { runoff volume and remove } \\
\text { rainfall-runoff pollutants }\end{array}$ \\
\hline 7 & $\begin{array}{l}\text { Zhang et al., } \\
2019\end{array}$ & $\begin{array}{l}\text { To examine the performance of a } \\
\text { mixed-flow bioretention system }\end{array}$ & China & $\begin{array}{l}\text { Physical } \\
\text { Modelling }\end{array}$ & LID & Bio-retention system & $\begin{array}{l}\text { The mixed-flow bio-retention } \\
\text { can effectively improve TN and } \\
\text { COD mass removal. }\end{array}$ \\
\hline 8 & $\begin{array}{l}\text { Song and } \\
\text { Song., } 2018\end{array}$ & $\begin{array}{l}\text { To evaluate the performance of } \\
\text { an artificial bioretention system }\end{array}$ & China & $\begin{array}{l}\text { Physical } \\
\text { Modelling }\end{array}$ & LID & Bio-retention system & $\begin{array}{l}\text { Bio-retention systems have } \\
\text { favorable removal effect on }\end{array}$ \\
\hline
\end{tabular}




\begin{tabular}{|c|c|c|c|c|c|c|c|}
\hline SN & Documents & Study aims & $\begin{array}{l}\text { Geographic } \\
\text { al region }\end{array}$ & Methods & Terminologies & Type of NBS & Key Findings \\
\hline & & & & & & & Phosphorus in rainwater runoff. \\
\hline 9 & $\begin{array}{l}\text { Wan et al. } \\
2018\end{array}$ & $\begin{array}{l}\text { To evaluate the performance of } \\
\text { wood-chip bioretention system }\end{array}$ & China & $\begin{array}{l}\text { Monitoring } \\
\text { / Analysis }\end{array}$ & LID & Bio-retention system & $\begin{array}{l}\text { For the field performance, } \\
\text { wood-chip bio-retention system } \\
\text { effectively removes nitrogen. }\end{array}$ \\
\hline 10 & Li et al., 2021 & $\begin{array}{l}\text { To assess the performance of } \\
\text { inverted bioretention }\end{array}$ & China & $\begin{array}{l}\text { Physical } \\
\text { Modelling }\end{array}$ & LID & Bio-retention system & $\begin{array}{l}\text { i. Increased efficiency for the } \\
\text { total runoff reduction and peak } \\
\text { flow reduction by inverted bio- } \\
\text { retention system. } \\
\text { ii. Good performance on nitrate } \\
\text { removal was exhibited }\end{array}$ \\
\hline 11 & $\begin{array}{l}\text { Liew et al., } \\
2012\end{array}$ & $\begin{array}{l}\text { Evaluation of detention pond for } \\
\text { stormwater quantity control }\end{array}$ & Malaysia & $\begin{array}{l}\text { Numerical } \\
\text { modelling }\end{array}$ & MSMA & Dry detention pond & $\begin{array}{l}\text { The detention pond achieved } \\
\text { the goal by catering the flow and } \\
\text { protecting against flooding }\end{array}$ \\
\hline 12 & $\begin{array}{l}\text { Ayub et } \\
\text { al.,2015 }\end{array}$ & $\begin{array}{l}\text { Green roof tested for high } \\
\text { intensity stormwater runoff for } \\
\text { quantity and quality of metals } \\
\text { (Lead and potassium) }\end{array}$ & Malaysia & $\begin{array}{l}\text { Physical } \\
\text { Modelling }\end{array}$ & $\begin{array}{l}\text { BMP, SUDs and } \\
\text { MSMA }\end{array}$ & Green roof & $\begin{array}{l}\text { The results showed that } \\
\text { reduction in the runoff for high } \\
\text { intensity stormwater was very } \\
\text { promising. }\end{array}$ \\
\hline 13 & $\begin{array}{l}\text { Shaharuddin } \\
\text { et al.,2014 }\end{array}$ & $\begin{array}{l}\text { To use constructed wetlands for } \\
\text { stormwater quality control }\end{array}$ & Malaysia & $\begin{array}{l}\text { Monitoring } \\
\text { / Analysis }\end{array}$ & MSMA & Constructed wetland & $\begin{array}{l}\text { The concentration of nutrients } \\
\text { such as nitrogen, phosphate } \\
\text { nitrite, nitrate, ammonia was } \\
\text { significantly reduced }\end{array}$ \\
\hline 14 & $\begin{array}{l}\text { Sim et al., } \\
2008\end{array}$ & $\begin{array}{l}\text { To use constructed wetland to } \\
\text { treat surface runoff from } \\
\text { developed urban area }\end{array}$ & Malaysia & $\begin{array}{l}\text { Monitoring } \\
\text { / Analysis }\end{array}$ & MSMA & Constructed wetland & $\begin{array}{l}\text { The removal efficiency of } \\
\text { nutrients was satisfactory for } \\
\text { Total nitrogen, nitrate and } \\
\text { phosphate. }\end{array}$ \\
\hline 15 & $\begin{array}{l}\text { Vojinovic et } \\
\text { al.,2021 }\end{array}$ & $\begin{array}{l}\text { To examine the efficacy of } \\
\text { different types of NBS (i.e., small- } \\
\text { and large-scale NBS) and their }\end{array}$ & Thailand & $\begin{array}{l}\text { Interviews } \\
\text { / } \\
\text { Numerical }\end{array}$ & NBS and EBA & $\begin{array}{l}\text { Small-scale and Large- } \\
\text { scale NBS }\end{array}$ & $\begin{array}{l}\text { i. The effectiveness of small- } \\
\text { scale NBS is limited to smaller } \\
\text { rainfall events }\end{array}$ \\
\hline
\end{tabular}




\begin{tabular}{|c|c|c|c|c|c|c|c|}
\hline SN & Documents & Study aims & $\begin{array}{l}\text { Geographic } \\
\text { al region }\end{array}$ & Methods & Terminologies & Type of NBS & Key Findings \\
\hline & & $\begin{array}{l}\text { hybrid combinations with grey } \\
\text { infrastructure }\end{array}$ & & modelling & & & $\begin{array}{l}\text { ii. The extreme events require } \\
\text { combinations of different kinds } \\
\text { of measures (hybrid measures) }\end{array}$ \\
\hline 16 & $\begin{array}{l}\text { Majidi et } \\
\text { al.,2019 }\end{array}$ & $\begin{array}{l}\text { To assess the effectiveness of } \\
\text { small-scale urban nature-based } \\
\text { solutions to reduce flooding and } \\
\text { enhance human thermal comfort }\end{array}$ & Thailand & $\begin{array}{l}\text { Numerical } \\
\text { modelling }\end{array}$ & BMP and NBS & $\begin{array}{l}\text { Green roof, Pervious } \\
\text { pavement, } \\
\text { Bioretention, Rain } \\
\text { garden }\end{array}$ & $\begin{array}{l}\text { The usage of a variety of various } \\
\text { solutions at different sites can } \\
\text { lead to effective flood mitigation } \\
\text { and thermal comfort increase. }\end{array}$ \\
\hline 17 & $\begin{array}{l}\text { Haddis et } \\
\text { al.,2020 }\end{array}$ & $\begin{array}{l}\text { To evaluate the performance of } \\
\text { constructed wetland in a tropical } \\
\text { climate under suboptimal } \\
\text { conditions of flow }\end{array}$ & $\begin{array}{l}\text { Ethiopia } \\
\text { (East Africa) }\end{array}$ & $\begin{array}{l}\text { Monitoring } \\
\text { / Analysis }\end{array}$ & Others & Constructed wetland & $\begin{array}{l}\text { i. Constructed wetlands can } \\
\text { function well under irregular } \\
\text { flow conditions } \\
\text { ii. Can be the technology of } \\
\text { choice in low income countries } \\
\text { (particularly in tropical climates). }\end{array}$ \\
\hline 18 & $\begin{array}{l}\text { Belle et } \\
\text { al.,2018 }\end{array}$ & $\begin{array}{l}\text { To investigate the effectiveness } \\
\text { of NBS to reduce drought, veld } \\
\text { fires and floods using wetlands }\end{array}$ & South Africa & $\begin{array}{l}\text { Questionna } \\
\text { ires / } \\
\text { interviews } \\
\text { / field } \\
\text { observatio } \\
\text { ns. }\end{array}$ & Others & Wetlands & $\begin{array}{l}\text { Healthy wetlands are effective } \\
\text { buffers in reducing disaster risks } \\
\text { such as drought, veld fires and } \\
\text { floods }\end{array}$ \\
\hline 19 & $\begin{array}{l}\text { Filho et al., } \\
2021\end{array}$ & $\begin{array}{l}\text { To assess the performance of } \\
\text { constructed wetland for the } \\
\text { Greywater treatment under } \\
\text { Tropical Conditions }\end{array}$ & Brazil & $\begin{array}{l}\text { Monitoring } \\
\text { / Analysis }\end{array}$ & Others & Constructed wetland & $\begin{array}{l}\text { The outputs of the study: } \\
\text { i. Will contribute to optimal } \\
\text { design and operation of a } \\
\text { Constructed wetlands } \\
\text { ii. Will contribute with empirical } \\
\text { data to Constructed wetlands } \\
\text { guidelines in Brazil }\end{array}$ \\
\hline
\end{tabular}




\begin{tabular}{|c|c|c|c|c|c|c|c|}
\hline SN & Documents & Study aims & $\begin{array}{l}\text { Geographic } \\
\text { al region }\end{array}$ & Methods & Terminologies & Type of NBS & Key Findings \\
\hline 20 & $\begin{array}{l}\text { de Macedo } \\
\text { et al.,2019a }\end{array}$ & $\begin{array}{l}\text { To assess the performance of a } \\
\text { bioretention basin in a } \\
\text { subtropical climate area }\end{array}$ & Brazil & $\begin{array}{l}\text { Monitoring } \\
\text { / Analysis }\end{array}$ & LIDs & Bio-retention system & $\begin{array}{l}\text { i. Delayed and reduced peak } \\
\text { flows. } \\
\text { ii. Retained greater volume of } \\
\text { runoff }\end{array}$ \\
\hline
\end{tabular}




\subsection{THE "OLD" CONCEPTS}

\section{i. LOW IMPACT DEVELOPMENT (LID)}

The phrase "low impact development" (LID) is generally used in North America and New Zealand. Barlow et al. (1977) are credited with being the first to make use of the term in a land use planning report in Vermont, USA. The LID can be defined as the approaches for reducing impervious cover and maintaining/retaining natural areas through site design. In recent years, low-impact development approaches have been applied in several studies for numerous nations in the Global South. In two studies conducted by Macedo et al. (2019a and 2019b) for stormwater management in Brazil, bioretention systems (a technology of Low Impact Development practices) were shown to postpone and reduce peak flows, and the system retained a greater amount of runoff volume. Furthermore, the peak flow attenuation was significant.

\section{ii. BEST MANAGEMENT PRACTICE (BMP)}

The term "best management practice" (BMP) indicates a systematic method to pollution avoidance that was developed in North America, specifically the United States of America and Canada. It also refers to stormwater management strategies that address one or both of the water quality and quantity concerns.

In the context of stormwater management, BMPs link non-structural interventions (such as good housekeeping and preventive maintenance) with structural deployments (such as bioretention systems or green infrastructure) to achieve the overall goal of pollution control. Individual and combined LIDBMPs for urban stormwater management were examined in Malaysia.

Goh et al., 2017 used enhanced bioretention with carbon source additive in a Mesocosm study (Engineering Campus Universiti Sains Malaysia USM, Nibong Tebal, Penang, Malaysia) to investigate nutrient removal efficiency and found that bioretention has a potential application for nutrient rich stormwater in mixed land.

Furthermore, Chang et al., 2018 conducted a field study in Kwasa Damansara, Selangor, Malaysia, using an engineered channel ecological swale and a detention pond to investigate the use of a treatment train for stormwater issues such as flooding and runoff quality control. They discovered that the treatment train was the long-term solution for stormwater issues i.e., floods and runoff quality control.

\section{iii. SUSTAINABLE URBAN DRAINAGE SYSTEMS (SUDS)}

The term "sustainable urban drainage systems" (SUDS) was described in an extensive set of standards published in 2000, which included design manuals that were equivalent but not identical for England, Scotland, Northern Ireland, and Wales (CIRIA, 2000).

SUDS are a collection of technologies and methods for draining stormwater/surface water that are more environmentally friendly than traditional approaches. SuDS in England and Wales are more concerned with water quantity control than with water quality control.

\section{iv. WATER SENSITIVE URBAN DESIGN (WSUD)}

Mouritz (1992) was the first practitioner in Australia to use the phrase "water sensitive urban design" (WSUD), which was swiftly followed by Whelans et al. in a report for the Western Australian Government (1994). The Water Supply, Sewerage, and Stormwater Management (WSUD) initiative covers all aspects of integrated urban water cycle management, including water supply, sewerage, and stormwater management. The United Nations' World Summit on Sustainable Development sparked a slew of related concepts, including climate-sensitive urban development (Coutts et al., 2013). 


\subsection{THE "NEW" WAVES}

\section{i. NATURE BASED SOLUTIONS (NBS)}

Approaches to developing new transdisciplinary knowledge and applications in urban ecosystems have evolved and integrated a number of metaphors throughout the previous half-century. In roughly chronological order, ecosystem services (ES), green infrastructure (GI), and, more recently, nature-based solutions are presented (NBS).

The International Union for Conservation of Nature (IUCN) is a prominent supporter of NBS, and in 2020, it will launch the Global Standard for NBS. NBS is defined by the IUCN as "activities to protect, sustainably manage, and restore natural and modified ecosystems in ways that effectively and adaptively solve societal concerns, providing both human welfare and biodiversity benefits." The necessity of recognizing the necessity to create mutual benefits for people and the ecosystem is emphasized in the concept.

According to the authors of the 2018 UN World Water Development Report (WWAP 2018), NBS can help in three areas: enhanced water availability, improved water quality, and reduced water-related risks.

There are numerous researches that address the advantages of adopting NBS. Cui et al., 2021, for example, relates the narrative of two cities, describing Singapore and Lisbon's paths toward developing adaptive and resilient urban water management strategies utilizing NBS. Through NBS, these cities have been transitioning from concrete "grey" infrastructure to "blue and green" infrastructure, despite their historical, climatic, economic, and cultural differences. These cities have shown how to turn ecological challenges into opportunities by implementing NBS, changing urban environments into healthy and enjoyable places to visit, live, and work. Figure 2 shows the ecosystem services provided by naturebased solutions.

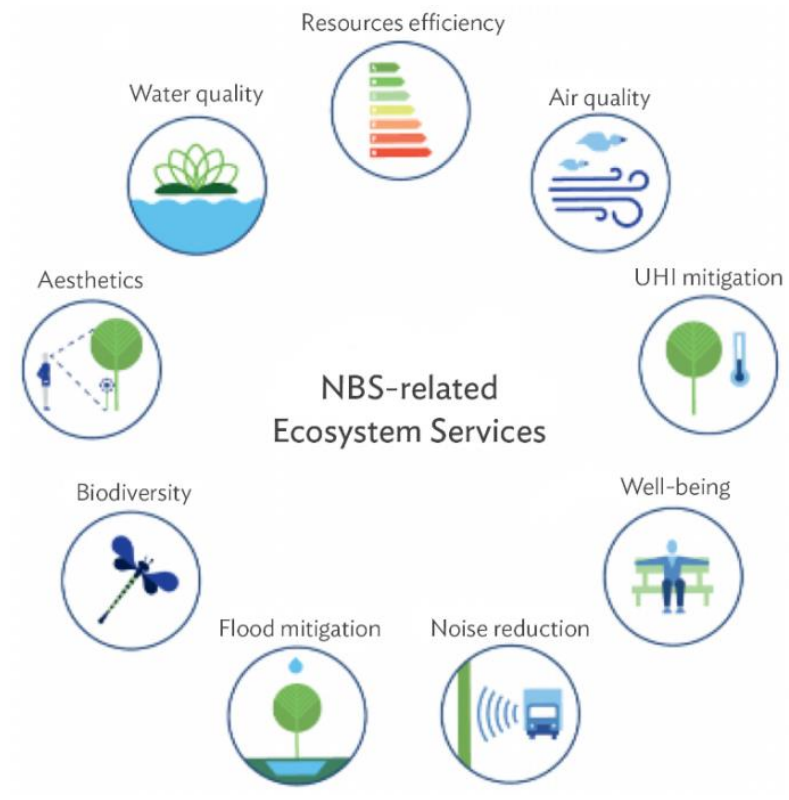

Fig. 2. NBS = nature-based solution, $\mathrm{UHI}=$ urban heat island (Adopted from Bozovic et al., 2017)

\section{ii. ECOSYSTEM BASED ADAPTATION (EBA)}

Ecosystem-based adaptation (EBA), which is defined as methods that leverage natural or managed biophysical systems (ecosystems) and processes to achieve adaptation goals, is gaining popularity as a useful tool for improving soil and water conservation strategies and agricultural development. EBA provides a broad array of advantages that concentrate on ecosystem repair, conservation, and long- 
term management. By restricting nutrient and sediment input in rivers and streams, EBA measures have a significant impact on sustaining surface water quality (Gathagu et al., 2018).

Filter strips, sediment ponds, grassed rivers, grade stabilization structures, stream stabilization structures, and agricultural management methods are examples of EBA structural measures. No-tillage and nutrient management strategies are examples of non-structural EBA measures.

Many scholars have recently discovered EBA to be a beneficial strategy for addressing water-related challenges in the Global South. Babel et al., 2021, for example, discussed the value of incorporating EBA measures into sediment management strategies to combat watershed deterioration in Thailand. Despite the growing adoption of EBA around the world, there is little research on its efficiency and efficacy in countries like Thailand and the rest of the Global South.

\section{iii. NATURE BASED SOLUTIONS PROJECTS IN KINGDOM OF THAILAND}

In Thailand, nature-based solutions are becoming more popular. Many NBS developments have been completed, including the Puey Ungphakorn Centenary Hall and Park and the Chulalongkorn University Centenary Park. The following is a brief explanation of the above-mentioned NBS projects and their goals.

\section{Puey Ungphakorn Centenary Hall and Park}

The Puey Ungphakorn Centenary Hall and Park is located in Thammasat University, Pathum Thani Province of Thailand with an area of approximately 60,000 square metres. The park is designed to tackle issues like climate change and urbanization. The main concern of the project is to manage and alleviate the risk of food and water scarcity. The park consists of a Green Roof Urban Farm" is the largest of its kind in Asia and the third largest in the world. The park's motto is to contribute to society and its residents in the form of clean air and reduced temperature inside the Puey Ungphakorn Centenary Hall.

\section{Chulalongkorn University Centenary Park}

This NBS projects is located in the heart of Bangkok with an area of about 44,800 square meters. The main concept of this project is to reduce risks of urban floods in surrounding areas. The design capacity of the park is approximately a million gallons of water. The components of this NBS project include a water retention pond, a constructed wetland, green roof, water retention lawn and rain garden. The park provides to the society in the form of urban flood mitigation, air pollution control and other services to the people like relaxing and exercise in its leisure area.

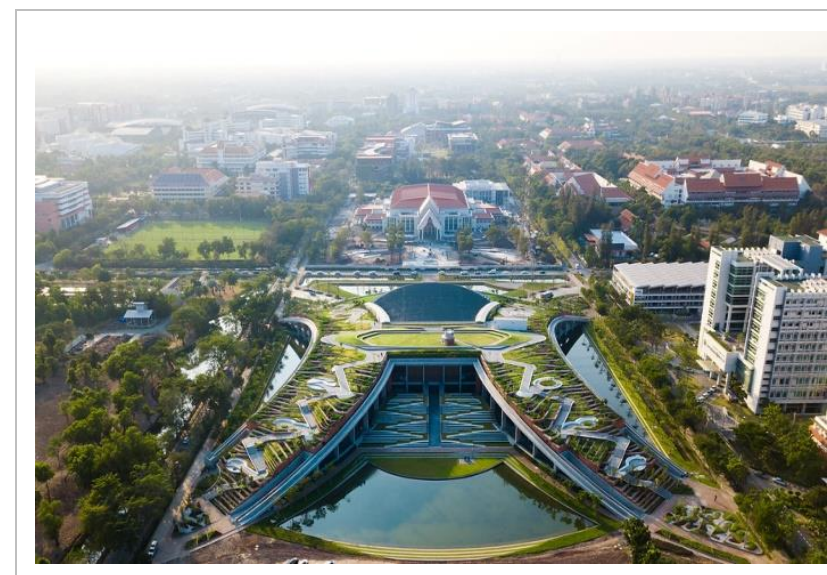

Puey Ungphakorn Centenary Hall and Park

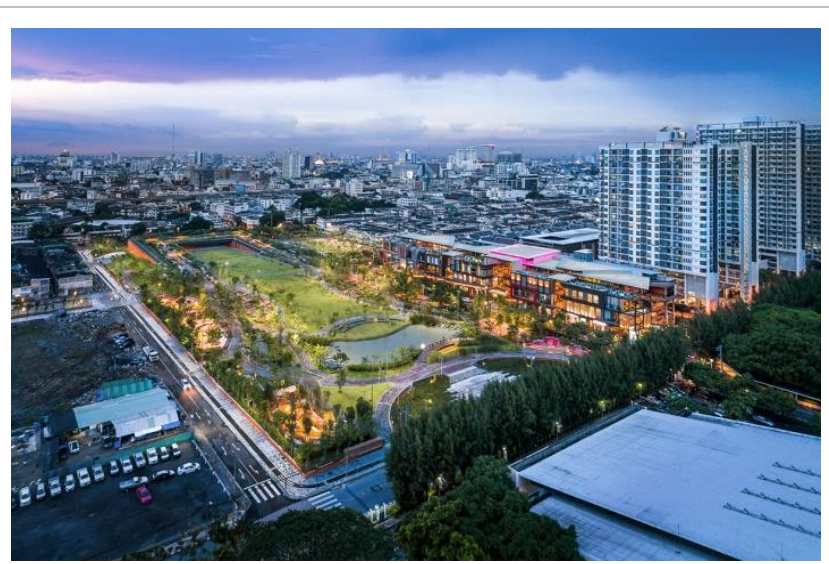

Chulalongkorn University Centenary Park 


\section{iv. SPONGE CITY STRATEGY}

The Chinese central government launched the Sponge City Initiative in 2014 to address stormwater issues (MOHURD, 2014). LIDs (Li et al., 2020), WSUDs, and SuDS are all techniques related to Sponge City. It does, however, have distinct regional characteristics due to rapid and expanded development, which has resulted in serious flooding and pollution challenges. Sponge City intends to employ NBS to execute stormwater management, with multi-functional goals such as reducing urban flood risk, capturing, purifying, and storing more rainwater for potable and non-potable uses, and providing additional ecological advantages through shared green areas (Chan et al., 2018).

\subsection{FUTURE OUTLOOKS}

Engineering and architecture must act together to design systems for urban water management that are centered on natural solutions. Because engineers are more concerned with managing water quantity and end up with grey infrastructure that ignores water quality, while architects are more concerned with aesthetics, other aspects such as biodiversity, economics, and social welfare are overlooked.

Consequently, a system that can provide all of the aforementioned benefits while still being lowmaintenance is desirable. Many regions in the global south have been plagued by calamities such as floods and droughts for decades, and because they are economically weak, the above-mentioned structure for urban water management is essential.

The Covid-19 pandemic has shown how vulnerable many of our city systems are. As the globe concentrates on economic recovery initiatives, which are likely to involve water management infrastructures and better water services, NBS for creating resilient, livable, affordable, and equitable cities should receive special emphasis. The Covid-19 recovery plans provide a fantastic opportunity to expand NBS in Global South countries, with the objective of better protecting, conserving, and rebuilding ecosystems and their services.

\section{CONCLUSIONS}

Given the global rise in urbanization, changing climate, and urban stormwater repercussions on human and marine habitats, urban water management is a crucial topic. The urban water cycle and drainage management have seen significant changes throughout time. LIDs, SUDs, WSUDs, and BMPs, among other techniques, have been accepted by the Global North to solve challenges (especially urban floods and water pollution) connected to urban water drainage and management, and these strategies have shown to be beneficial in resolving the aforementioned difficulties.

Considering the Global South, there has been a favorable tendency in the past decades to adapt naturefriendly approaches such as sponge cities in China and EBA in various locations of the Global South. These approaches and strategies have mostly been adapted from the Global North to countries in the Global South. However, due to climate differences (temperate climate in the Global North vs. mostly tropical climate in the Global South), it is difficult to achieve fruitful results (due to changes in meteorological and hydrological conditions) by implementing those approaches in many regions of the Global South (i.e., Thailand, Malaysia, Singapore, Brazil, African countries etc.).

Because the region we're concerned about is mostly made up of poor countries with weak economies, there are barriers to implementing new policies like NBS and EBA, such as associated costs and local people's desire.

Therefore, the study concludes that public awareness and collaboration from local government entities are needed to implement NBS for urban drainage. As the globe faces numerous issues, such as changing climate, overpopulation, and rapid urbanization, anomalies in the hydrologic cycle result in floods and droughts, among other things; on the other side, dirty water disrupts aquatic ecosystems and biodiversity. There is a critical need to use efficient initiatives such as NBS. 


\section{REFERENCES:}

(1) Ayub K R., A A Ghani., N A Zakaria. (2015). Green Roof: Vegetation Response towards Lead and Potassium, 1st Young Sci. Int. Conf. Water Resour. Dev. Environ. Prot. no June. 5-7.

(2) Babel, M.S., Gunathilake, M.B., Jha, M.K. (2021). Evaluation of Ecosystem-Based Adaptation Measures for Sediment Yield in a Tropical Watershed in Thailand. Water, 132767. https://doi.org/10.3390/w13192767.

(3) Belle, J.A., Collins, N. \& Jordaan, A. (2018). Managing wetlands for disaster risk reduction: A case study of the eastern Free State, South Africa, Jàmbá: Journal of Disaster Risk Studies 101 a400. https://doi.org/10.4102/jamba.v10i1.400.

(4) Bozovic, R., C. Maksimovic, A. Mijic, M. Van Reeuwijk, K. Smith, and I. Suter. (2017). Blue Green Solutions, A Systems Approach to Sustainable, Resilient and Cost-Efficient Urban Development. Imperial College London. Blue Green Dream project, Climate-KIC, European Institute for Innovation and Technology.

(5) Chan, F.K.S., et al., (2018). "Sponge City" in China-a breakthrough of planning and flood risk management in the urban context. Land Use Policy 76, 772-778.

(6) Chang C K., N A Zakaria., M R Othman. (2018). MATEC Web Conf. 24601112.

(7) CIRIA, (2000). Sustainable urban drainage systems - design manual for Scotland and Northern Ireland. Dundee, Scotland: CIRIA Report No. C521.

(8) CIRIA. (2015). The SuDS manual. https://www.ciria.org.

(9) Coutts, A.M., Tapper, N.J., Beringer, J., Loughnan, M., and Demuzere, M., (2013). Watering our cities the capacity for Water Sensitive Urban Design to support urban cooling and improve human thermal comfort in the Australian context. Progress in Physical Geography, 37 (1), 2-28.

(10)Cui, M.; Ferreira, F.; Fung, T.K.; Matos, J.S. (2021). Tale of Two Cities: How Nature-Based Solutions Help Create Adaptive and Resilient Urban Water Management Practices in Singapore and Lisbon. Sustainability, 13, 10427. https://doi.org/10.3390/ su131810427.

(11)Dagenais, D., Brisson, J., Fletcher, T.D. (2018). The role of plants in bioretention systems; does the science underpin current guidance? Ecol. Eng. 120 532-545.

(12)De Macedo, M.B., Ambrogi Ferreira do Lago, C., Mendiondo, E.M., M, H.G. (2019a). Bioretention performance under different rainfall regimes in subtropical conditions: a case study in Sao Carlos, Brazil. J. Environ. Manag. 248109266.

(13)De Macedo, M.B., do Lago, C.A .F., Mendiondo, E.M., (2019b). Stormwater volume reduction and water quality improvement by bioretention: potentials and challenges for water security in a subtropical catchment. Sci. Total Environ. 647, 923-931.

(14)Department of Irrigation and Drainage Malaysia (DID). (2012). Urban Stormwater Management Manual for Malaysia (MSMA). Kuala Lumpur, Malaysia.

(15)European Commission. (2019). Natural Capital Accounting: Overview and Progress in the EuropeanUnion, 6th Report. https://ec.europa.eu.

(16)Fletcher, T. D., et al. (2015). SUDS, LID, BMPs, WSUD and more - The evolution and application of terminology surrounding urban drainage. Urban Water Journal, 12(7) 525-542. https://doi.org/10.1080/1573062X.2014.916314. 
(17)Gathagu, J.N.; Sang, J.K.; Maina, C.W. (2018). Modelling the Impacts of Structural Conservation Measures on Sediment and water yield in Thika-Chania Catchment, Kenya. Int. Soil Water Conserv. Res. 6, 165-174.

(18)Goh H W., N A Zakaria ., T L Lau., K Y Foo., C K Chang., C S Leow. (2017). Urban Water J. 142 134142.

(19)Haddis A., Bruggen B V d., Smets I. (2020). Constructed wetlands as nature based solutions in removing organic pollutants from wastewater under irregular flow conditions in a tropical climate, Ecohydrology \& Hydrobiology. 20 38-47.

(20)Jiayu Gao, Jiake Lia, Yajiao Li, Jun Xia, Peng Lv. (2021). A Distribution Optimization Method of Typical LID Facilities for Sponge City Construction, Ecohydrology \& Hydrobiology 21, 13-22.

(21)Kabir, M.I., Daly, E., Maggi, F. (2014). A review of ion and metal pollutants in urban green water infrastructures. Sci. Total Environ. 470-471, 695-706.

(22)Li, L., Collins, A.M., Ali Cheshmehzangi, A., Chan, F.K.S., (2020). Identifying enablers and barriers to the implementation of the Green Infrastructure for urban flood management: A comparative analysis of the UK and China. Urban For. Urban Green. 54, 126770.

(23)Liew Y S., Z Selamat., A A Ghani ., N A Zakaria. (2012). Performance of a dry detention pond: case study of Kota Damansara, Selangor, Malaysia, Urban Water J. 92 129-136.

(24)Loc, H. H., Babel, M. S., Weesakul, S., Irvine, K. N., \& Duyen, P. M. (2015). Exploratory assessment of SUDS feasibility in Nhieu Loc-Thi Nghe Basin, Ho Chi Minh City, Vietnam. British Journal of Environment and Climate Change, 5(2), 91-103.

(25)Loc, H. H., Duyen, P. M., Ballatore, T. J., Lan, N. H. M., \& Gupta, A. D. (2017). Applicability of sustainable urban drainage systems: an evaluation by multi-criteria analysis. Environment Systems and Decisions, 37(3), 332-343.

(26)Luo, Y., Yue, X., Duan, Y., Zhou, A., Gao, Y., Zhang, X., (2020). A bilayer media bioretention system for enhanced nitrogen removal from road runoff. Sci. Total Environ. $70 \quad 5 \quad 135893$. https://doi.org/10.1016/j.scitotenv.2019.135893.

(27)Magalhães Filho, F.J.C.; de Souza Filho, J.C.M.; Paulo, P.L. (2021). Multistage Constructed Wetland in the Treatment of Greywater under Tropical Conditions: Performance, Operation, and Maintenance. Recycling, 6, 63. https:// doi.org/10.3390/recycling604006.

(28) MOHURD (2014) (Ministry of Housing and Urban-Rural Development of the People's Republic of China), Technical Guidelines for Sponge City Construction (in Chinese).

(29)Mouritz, M., (1992). Sustainable urban water systems; policy \& pofessional praxis. Perth, Australia: Murdoch University.

(30)Muerdter, C.P., Wong, C.K., LeFevre, G.H. (2018). Emerging investigator series: the role of vegetation in bioretention for stormwater treatment in the built environment: pollutant removal, hydrologic function, and ancillary benefits. Environ. Sci.: Water Res. Technol. 4 (5) 592-612.

(31)Nguyen, H. Q., Radhakrishnan, M., Bui, T. K. N., Tran, D. D., Ho, L. P., Tong, V. T., ... \& Ho, H. L. (2019). Evaluation of retrofitting responses to urban flood risk in Ho Chi Minh City using the motivation and ability (MOTA) framework. Sustainable Cities and Society, 47, 101465.

(32)PUB. (2018). Active, Beautiful, Clean Waters Design Guidelines, fourth Ed. https:// www.pub.gov.sg/Documents/ABC_Waters_Design_Guidelines.pdf. 
(33)Ren,N., Wang, Q., Wang, Q., Huang, H., Wang, X. (2017). Upgrading to urban water system 3.0 through sponge city construction. Front. Environ. Sci. Eng. 11 9. Retrieved from http://water. epa.gov/infrastructure/greeninfrastructure/index.cfm.

(34)Revi A, Satterthwaite D.E., Aragón-Durand F., Corfee-Morlot D., Kiunsi R.B.R., Pelling M., Solecki W., Urban areas: Field C.B., Barros V.R., Dokken D.J., Mach K.J., Mastrandrea M.D., Bilir T.E., Chatterjee M., Ebi K.L., Estrada Y.O., Genova R.C., Girma B., Kissel E.S., Levy A.N., MacCracken S., Mastrandrea P.R., White (Eds.) L.L. (2014). Climate Change: Impacts, Adaptation and Vulnerability. Part A: Global and Sectoral Aspects. Contribution of Working Group II to the Fifth Assessment Report of the Intergovernmental Panel on Climate Change., Cambridge University Press, Cambridge, UK and New York, NY, USA

(35)Shaharuddin S., N W Chan., N A Zakaria., A A Ghani., C K Chang., R Roy. (2014). Constructed Wetlands as a Natural Resource for Water Quality Improvement in Malaysia Sci. Res. 0507 292-298.

(36)Sim C H., M K Yusoff., B Shutes., S C Ho., M Mansor. (2008). Nutrient removal in a pilot and full scale constructed wetland, Putrajaya city, Malaysia. J. Environ. Manage. 882 307-317.

(37)Song, Y., Song, S. (2018). Migration and transformation of different phosphorus forms in rainfall runoff in bioretention system. Environ. Sci. Pollut. Res, 3 1-8. https://doi. org/10.1007/s11356-0182405-4.

(38)Spahr, S., Teixid O, M., Sedlak, D.L., Luthy, R.G. (2020). Hydrophilic trace organic contaminants in urban stormwater: occurrence, toxicological relevance, and the need to enhance green stormwater infrastructure. Environ. Sci. Water Res. Technol. 6 15-44.

(39)UNDESA. (2012). World Urbanization Prospects: the 2012 Revision.

(40)USEPA. (2000). Low-Impact Development (LID): A Literature Review (Report), 35.

(41)USEPA. (2012). Green infrastructure.

(42)Vojinovic Z., Alves A, Gómez J P, Weesakul S, Keerakamolchai W., Meesuk V., Sanchez A. (2021). Effectiveness of small- and large-scale Nature-Based Solutions for flood mitigation: The case of Ayutthaya, Thailand. Science of the Total Environment. 789147725.

(43)Wan, Z.X., Li, T., Liu, Y.T. (2018). Effective nitrogen removal during different periods of a field scale bioretention system. A. Environ. Sci. Pollut. Res. 2517855 - 17861. https://doi.org/10.1007/s11356018-1954-x.

(44)Water by Design. (2014). Bioretention Technical Design Guidelines.

(45)WWAP (United Nations World Water Assessment Programme)/UN-Water. (2018). The United Nations World Water Development Report 2018: Nature-Based Solutions for Water; UNESCO: Paris, France.

(46)Yang, Y., Chui, T.F.M. (2018). Optimizing surface and contributing areas of bioretention cells for stormwater runoff quality and quantity management. J. Environ. Manag. 206 1090-1103.

(47)Yang, Y., Chui, T.F.M. (2018). Optimizing surface and contributing areas of bioretention cells for stormwater runoff quality and quantity management. J. Environ. Manag. 206 1090-1103.

(48)Yepeng Mai, Guoru Huang. (2021). Hydrology and rainfall runoff pollutant removal performance of biochar amended bioretention facilities based on field scale experiments in lateritic red soil regions, Science of the Total Environment. 76143252. 
(49)Yuqing Li, Yu Zhang, Heng Yu, Yuan Han, Jiane Zuo. (2021). Enhancing nitrate removal from urban stormwater in an inverted bioretention system. Ecological Engineering. 170106315.

(50)Zhang, W., Sang, M., Che, W., Sun, H. (2019). Nutrient removal from urban stormwater runoff by an up-flow and mixed-flow bioretention system. Environ. Sci. Pollut. Res. 26 17731-17739. https://doi.org/10.1007/s11356-019-05091-4.

(51)Zhang, Y.; Zhao, W.; Chen, X.; Jun, C.; Hao, J.; Tang, X.; Zhai, J. (2021). Assessment on the Effectiveness of Urban Stormwater Management.Water 13 4. https://doi.org/10.3390/w13010004.

(52)Zhaoyang You, Li Zhang, Shu-Yuan Pan, Pen-Chi Chiang, Silu Pei, Shujuan Zhang. (2019). Performance evaluation of modified bioretention systems with alkaline solid wastes for enhanced nutrient removal from stormwater runoff, Water Research 161 61-73. 